\title{
The Home Stay: A Gendered Perspective
}

\author{
Heather Gutel \\ Creighton University
}

\section{Introduction}

A home stay is typically defined as a period of time in which a person resides with a family in a home located outside his or her country of residence. Living with a host family is frequently connected to learning a language and immersion in a foreign culture. Study abroad students often participate in home stays, but there little academic research to-date that gives evidence of why students should (or should not) choose to live with a host family. No existing research was found that compares the home stay experiences of male and female study abroad participants.

International Studies Abroad (ISA) places many of their students with host families. The organization offers year, semester, summer, and intensive month programs in Belgium, Spain, Italy, France, Chile, Costa Rica, Argentina, Mexico, the Dominican Republic, England, and Australia. In ISA's Spain and Latin American sites, the majority of the students are placed with host families. This study explores the home stay experiences of male and female ISA students.

\section{Rese a r ch Q u stion}

The purpose of this research is to seek an understanding of the perceptions that male and female students hold towards living with a host family, to analyze what has shaped their experience and subsequently their views, and to generate a theory about the home stay perceived as a "gendered" experience. The questions that this research will explore are: "Is the home stay experience similar or different for male and female study abroad participants? If it is similar, how is it similar? If it is different, how is it different?" Sub-questions, related to this are "What aspects of the home stay are recognized by male students as significant or insignificant to their learning while abroad? What aspects are recognized by female students as significant or insignificant? What aspects of the home stay determined if the student had a satisfactory or unsatisfactory host family experience?"

\section{Defining the "Home Stay"}

The term "home stay" in this study refers to an environment in which a U.S.-based study abroad student lives with a local family. Each family has different characteristics such as age, number of family members, size of the home, and family personalities. The family could consist of a single parent 
with children, a retired couple, or a two-parent family with children. The host families provide meals, laundry, and accommodation for the student (or students) in their home. The duration of the home stay is dependent upon the length of the student's program: year, semester, summer, or month.

\section{Methodology}

Because there is no research precedent comparing the similarities and differences of home stay experiences between male and female students, this study utilized grounded theory techniques in order to generate theory from the data collected. Additionally, within the confines of grounded theory, the study will employ the use of constant comparative analysis to code and extract a theory and other significant findings.

\section{Data Collection}

Surveys were sent to over 3,545 ISA participants in August 2004 asking them to answer rated questions about their host family experience abroad. The survey was distributed to all students who studied abroad in 2003 and 2004 on ISA year, semester, summer, and intensive month programs. At the conclusion of the survey, students were invited to include additional comments, concerns, or anecdotes about their home stay experience. This 'Additional Comments Section' was open-ended and allowed students to elaborate, or bring to the surface, feelings that were not covered by the survey questions. The survey, therefore, included both quantitative and qualitative data.

The research in this study primarily included undergraduate students from U.S. four-year degree granting universities or institutions. The students went abroad for different lengths of time: intensive month (3\%), summer (47\%), semester (48\%), and year (2\%). The respondent pool included a much smaller percentage of male students (18\%) than female students (82\%).

Table 1: $\quad$ Survey Respondents at ISA Study Abroad Sites

\begin{tabular}{|l|c|c|}
\hline ISA Site & $\begin{array}{l}\text { Number of } \\
\text { respondents }\end{array}$ & Percentage \\
\hline Argentina & 16 & $2.5 \%$ \\
\hline Chile & 36 & $5.7 \%$ \\
\hline Costa Rica & 88 & $14 \%$ \\
\hline Dominican Republic & 2 & $.32 \%$ \\
\hline France & 15 & $2.4 \%$ \\
\hline Mexico & 68 & $10.8 \%$ \\
\hline Spain & 398 & $63.4 \%$ \\
\hline Multi-Country & 5 & $.8 \%$ \\
\hline
\end{tabular}


The majority of the respondents indicated on the survey that he or she had a roommate during his or her home stay experience. 452 respondents (72\%) lived with a roommate and 176 respondents (28\%) did not have a roommate during their program. The presence or absence of a roommate in the home stay may have affected how the student perceived his or her experience.

A list of 18 categories emerged from a list of key words commonly found in students' additional comments. Comparisons were constructed between male and female students qualitative responses (additional comments) and quantitative responses (survey data $\&$ percentages) in order to generate a theory that explains the data.

\section{Data and Results}

The data presented in Table 2 depicts the survey results, including tabulated percentages for each question for male and female responses. The additional comments included at the end of the survey contained many opinions and feelings with both positive and negative views. This qualitative data provided further insight into the male/female perspectives of the home stay experience. The additional comments were initially separated into three prominent groupings: exceptional home stay experiences, satisfactory home stay experiences, and unsatisfactory home stay experiences.

The 'exceptional' group consisted of comments that contained words such as, "amazing," "essential," "incredible," "wonderful," and "the best experience I had." The 'satisfactory' group included comments that did not express obvious excitement or disappointment about the student's host family experience. The students in this group generally expressed that they had a positive host family experience, but that they would not live with a host family again. The 'unsatisfactory' group consisted of comments from respondents who expressed displeasure and unhappiness about their home stay experience. The students in this group also included those who would not recommend living with a host family again and/or suggested finding one's own living arrangement (such as an apartment) for the duration of the study abroad experience.

After the comments were separated into these three broad groups, they were further divided into categories based on what each student wrote. The next section of this article summarizes the categories that were derived from the student comments. 
Table 2: $\quad$ Summary of Survey Questions (Percentages are rounded to the nearest whole number, and may equal more than $100 \%$ due to students selecting more than one answer per question)

\begin{tabular}{|l|c|l|}
\hline Female & Male & 1. Why did you choose to live with a host family? \\
\hline $25 \%$ & $27 \%$ & a) Only option/did not realize there were other options \\
$12 \%$ & $15 \%$ & b) Friend or Advisor recommendation \\
$65 \%$ & $63 \%$ & c) Wanted to live with locals \\
$1 \%$ & $2 \%$ & d) Was given a trial run option before committing \\
$3 \%$ & $3 \%$ & e) Did not want to look for my own housing \\
$4 \%$ & $3 \%$ & f) other \\
\hline Female & Male & 2. Did you have the option to change host families if there \\
& & was a problem? \\
\hline $14 \%$ & $14 \%$ & a) Don't Know \\
$2 \%$ & $.9 \%$ & b) No \\
$84 \%$ & $84 \%$ & c) Yes \\
\hline Female & Male & 3. If YES, did this option affect your decision of whether or \\
& & not to live with a host family? \\
\hline $14 \%$ & $22 \%$ & a) Not Applicable \\
$56 \%$ & $57 \%$ & b) No \\
$25 \%$ & $21 \%$ & c) Yes \\
\hline Female & Male & 4. Did you ever change host families? \\
\hline $94 \%$ & $94 \%$ & a) No \\
$6 \%$ & $6 \%$ & b) Yes \\
\hline Female & Male & 5. If yes, for what reason did you change? \\
\hline $96 \%$ & $94 \%$ & a) (blank) Not Applicable \\
$6 \%$ & $0.9 \%$ & b) Bad hygienic conditions \\
$2 \%$ & $2 \%$ & c) Personality clashes with family member(s) \\
$1 \%$ & $3 \%$ & d) Dietary needs not accommodated \\
$.8 \%$ & $0 \%$ & e) Allergies to home conditions \\
$1 \%$ & $.9 \%$ & f) Other \\
\hline Female & Male & 6. How Important was host family experience to learning \\
& & about the country's culture? \\
\hline $2 \%$ & $.9 \%$ & a) Not Important \\
$9 \%$ & $9 \%$ & b) Somewhat Important \\
$10 \%$ & $9 \%$ & c) Important \\
\hline $2 \%$ & $25 \%$ & d) Very Important \\
\hline
\end{tabular}


Table 2: Summary of Survey Questions (continued)

\begin{tabular}{|l|l|l|}
\hline Female & Male & $\begin{array}{l}\text { 7. How do you feel these aspects of host family living } \\
\text { affected (eased or impeded) your ability to explore the } \\
\text { culture outside of the home? }\end{array}$ \\
\hline $4 \%$ & $3 \%$ & $\begin{array}{l}\text { a) Made it much more difficult } \\
\text { b) Made it difficult }\end{array}$ \\
$31 \%$ & $9 \%$ & c) No affect \\
$30 \%$ & $32 \%$ & d) Made it easier \\
$22 \%$ & $23 \%$ & e) Made it much easier \\
\hline Female & Male & 8. How important was living with a host family to the \\
& & improvement of your language skills? \\
\hline $3 \%$ & $4 \%$ & a) Not Important \\
$8 \%$ & $4 \%$ & b) Somewhat Important \\
$10 \%$ & $11 \%$ & c) Important \\
$27 \%$ & $32 \%$ & d) Very Important \\
$52 \%$ & $48 \%$ & e) Essential \\
\hline
\end{tabular}

\begin{tabular}{|l|l|l|}
\hline Female & Male & 9. How often did your host family interact with you? \\
\hline $0.8 \%$ & $0.9 \%$ & a) Never \\
$6 \%$ & $3 \%$ & b) Rarely \\
$14 \%$ & $9 \%$ & c) Occasionally \\
$36 \%$ & $27 \%$ & d) Often \\
$44 \%$ & $60 \%$ & e) Very Often \\
\hline Female & Male & 10. How important do you feel host family interaction is to \\
& & the success of your study abroad experience? \\
\hline $2 \%$ & $3 \%$ & a) Not important \\
$5 \%$ & $8 \%$ & b) Somewhat important \\
$13 \%$ & $15 \%$ & c) Important \\
$37 \%$ & $29 \%$ & d) Very Important \\
$44 \%$ & $46 \%$ & e) Essential \\
\hline Female & Male & 11. To what extent did the host family make you feel \\
& & welcome? \\
\hline $3 \%$ & $3 \%$ & a) Very Unwelcome \\
$3 \%$ & $2 \%$ & b) Unwelcome \\
$12 \%$ & $10 \%$ & c) Somewhat Welcome \\
$23 \%$ & $18 \%$ & d) Welcome \\
$60 \%$ & $66 \%$ & e) Very Welcome \\
\hline Female & Male & 12. Would you recommend host family stays? \\
\hline $5 \%$ & $6 \%$ & (Blank) Indifferent \\
$4 \%$ & $5 \%$ & 1) No \\
$91 \%$ & $89 \%$ & 2) Yes \\
\hline Female & Male & 13. Would you recommend host family stays to someone \\
\hline $8 \%$ & $13 \%$ & who is extremely independent and resourceful? \\
\hline $74 \%$ & $15 \%$ & (Blank) Indifferent \\
\hline & $72 \%$ & 2) Yes \\
\hline
\end{tabular}


Table 2: $\quad$ Summary of Survey Questions (continued)

\begin{tabular}{|c|c|c|}
\hline Female & Male & 14. How would you rate your host family experience? \\
\hline $3 \%$ & $3 \%$ & $\begin{array}{l}\text { a) Unpleasant-I would never choose the host family option } \\
\text { again }\end{array}$ \\
\hline $3 \%$ & $3 \%$ & b) Unpleasant \\
\hline $16 \%$ & $9 \%$ & $\begin{array}{l}\text { c) Mediocre experience, but not rule out doing home stay } \\
\text { again }\end{array}$ \\
\hline $31 \%$ & $2 \%$ & d) Pleasant, enjoyed my stay with a host family \\
\hline $47 \%$ & $44 \%$ & $\begin{array}{l}\text { e) Very Pleasant, Couldn't imagine study abroad without } \\
\text { family }\end{array}$ \\
\hline Female & Male & $\begin{array}{l}\text { 15. If you had a negative host family experience, how } \\
\text { would the host family experience affect your decision to } \\
\text { study abroad in the future? }\end{array}$ \\
\hline $78 \%$ & $78 \%$ & (Blank) Not applicable-had positive experience \\
\hline $9 \%$ & $10 \%$ & a) Very Little affect on my decision \\
\hline $4 \%$ & $3 \%$ & b) No affect on my decision \\
\hline $4 \%$ & $0.9 \%$ & c) Indifferent \\
\hline $4 \%$ & $7 \%$ & d) Affect my decision \\
\hline $2 \%$ & $0.9 \%$ & e) Greatly affect my decision \\
\hline Female & Male & $\begin{array}{l}\text { 16. How important was your host family experience to the } \\
\text { success of your overall study abroad experience? }\end{array}$ \\
\hline $4 \%$ & $4 \%$ & a) Not important \\
\hline $7 \%$ & $10 \%$ & b) Somewhat important \\
\hline $22 \%$ & $18 \%$ & c) Important \\
\hline $34 \%$ & $26 \%$ & d) Very Important \\
\hline $32 \%$ & $43 \%$ & e) Essential \\
\hline
\end{tabular}

\section{Categories of Analysis}

The categories that were used in the analysis of the qualitative data directly emerged from the data provided by the respondents.

\section{Category 1: Language and Culture}

This category includes comments in which respondents felt that the host family either benefited or hindered their language learning or cultural exposure. Many participants felt that the host family provided insights into the host culture that would otherwise be unobtainable for 'simple tourists.'

\section{Category 2: Freedom, Independence \& Privacy}

This category includes comments in which respondents felt that the host family either allowed or prevented them from being 'independent' and having privacy during their stay. Participants who made comments regarding freedom, independence, and privacy often identified themselves as "independent persons." It may be beneficial to conduct further research inquiring how the term 'independent' is being defined by undergraduate study abroad 
participants and how this definition affects the participant's perspective of his/ her host family experience.

\section{Category 3: Treated as Part of Family}

This category emerged from comments that illustrated how a student was incorporated into the everyday life of the host family and "treated like their second daughter/son." Respondents who commented on their inclusion or noninclusion within the family unit many times attributed the success or failure of their home stay experience to this treatment.

\section{Category 4: Student Still In Touch With Host Family}

This category was a surprising discovery because it is the only category that does NOT describe characteristics of the home stay at the time of the actual experience. Moreover, students who mentioned this aspect were those students who fell in the 'exceptional home stay experience' category. Students from the other two categories (satisfactory home stay experience, unsatisfactory home stay experience) did not comment about continued communication with the host family.

\section{Category 5: Overall Match}

This category encompassed a broad range of responses. Many respondents felt that the success or failure of their home stay experience was simply due to the "luck of the draw" and described getting along or not getting along well with host family members. Participants who fell in this category also gave general comments about their home stay explaining how they liked or disliked their host family.

\section{Category 6: Interaction with Locals/Family}

This category developed from respondents who commented that their host families allowed them or assisted them in 'interacting with locals.' Based on these responses, this type of interaction seems to be accomplished by meeting friends of the family or being instructed by the host family regarding the guidelines of interacting within the host culture.

\section{Category 7: Acclimate to New Environment}

This category emerged from comments about how the host family helped to make the student's transition to a foreign environment easier. The highlights of this category included host families who took the time and effort to 
give tours of the area surrounding their home, to show the student bus stops or how to get to school, and to answer questions about their culture.

\section{Category 8: Make-Up of the Host Family}

This category includes comments about the characteristics of the host family such as age, size, and number of family members. Many respondents mentioned that having kids in the family was helpful in learning the language and culture as well as meeting and interacting with other local people, generally the friends of the host siblings.

\section{Category 9: Family Experienced in Housing Students}

This category includes comments that were made regarding the host family's past experience (or lack of) with hosting students. Comments within this category were uncommon; however, a few students explicitly wrote that the family's past experience affected his or her home stay.

\section{Category 10: Companionship, Friendship, \& Caring}

This category arose from comments about how the host family provided the student with a sense of 'being cared for.' The term "caring" that was mentioned by the respondents, seemed to also signify companionship and friendship from members of the host family.

\section{Category 11: Services}

This category surfaced from students who commented upon meals, food, laundry, accommodations, and hygienic conditions of the home stay. It is important to note that students, who had negative comments about the "services" of the host family, related the 'bad service' to having an unsatisfactory experience. It was obvious that many comments in this section could be attributed simply to cultural differences; however, the respondents oftentimes did not seem to be able to make this connection.

\section{Category 12: Welcoming and Comfortable Environment, Home Away From Home}

This category included comments describing the atmosphere or environment of the home stay. Responses indicated positive home stay experiences from those students who felt comfortable in the home and welcomed by the host family. Similarly, responses from the students who did not feel comfortable or welcomed in their home stay environment point towards a more negative experience. 


\section{Category 13: Expectations}

This category represents comments by students who noted that they had very high or very low expectations of the home stay before their arrival. It was common that students who had very high expectations of the home stay, oftentimes made comparisons of how foreign students are treated by host families in the United States. More research would need to be conducted in order to fully determine the reason behind the expectations held by prospective study abroad participants. The responses in this category, whether a student had higher or lower expectations, did not seem to greatly affect the student's opinion of the overall home stay experience.

\section{Category 14: Family's Reason for Hosting}

This category presented reasons as to why the host family decided to host a student. Responses that fell in this category were primarily from those students who were judged to have unsatisfactory home stay experiences. Responses outlining the family's reasons for hosting most commonly included mentions of the host family having accepted students for monetary purposes only. It is important to note that the students who mentioned that their host family hosted students as a source of income, also held the expectation that he/she would be treated as a part of the family. Students who had exceptional or satisfactory host family experiences rarely made comments within this category.

\section{Category 15: Alternate Living Arrangements}

This category included comments in which the respondent felt that $\mathrm{s} / \mathrm{he}$ would prefer other living arrangements, such as apartment or dorm style living, instead of a home stay. The majority of comments within this category were made by students who had unsatisfactory host family experiences or those students who felt they were too "independent" for host family living.

\section{Category 16: Family Met Student's Needs, Accommodating}

This category arose from comments by students who felt that the host family either met or did not meet their needs while abroad. These needs generally included both the physical and emotional needs of the student. Within this category it is significant to note that the students, whose needs were accommodated by the family, connected this to having had an exceptional home stay experience. Nevertheless, it was rarely mentioned how the student accommodated the needs of the host family. 


\section{Category 17: Roommates or Other Students}

This category included comments from students whose host family experience was influenced by a roommate or by other students also residing in the home. Some students enjoyed having other students in the home because it provided additional interaction in the home stay environment. Others, however, felt that having a roommate or other students in the home had a negative impact on language learning.

\section{Category 18: Miscellaneous, Other}

This category consists of students' comments that did not fall into any of the aforementioned categories. These responses included those that were vague or simply provided a reaction to the home stay experience.

The majority of the respondents' additional comments fit more than one of the 18 categories presented above. The following table presents the top five categories that were mentioned by male and female students, in addition to whether the student had an exceptional, satisfactory, or unsatisfactory home stay experience. These five categories were determined by generating percents for each category based on the number of students who mentioned the corresponding topic (category) in his/her additional comment. The data in the table is a summary of the categories that were most frequently mentioned by the respondents.

One major finding demonstrated by the above table, is that the "Language \& Culture (Immersion, Learning) Category" was the number one category in each group, except for females who had unsatisfactory home stay experiences. A second significant finding is that the "Freedom, Independence \& Privacy Category" is the first or second category in each group. A third finding, is that the "Treated as Part of the Family Category" is included as one of the top 5 categories for females who had exceptional, satisfactory and unsatisfactory home stays experiences; however, this was not included in any of the top 5 categories for the male respondents.

\section{Assessment of Data and Generation of Theory}

The respondents to the ISA Host Family Survey answered that the primary reason $(65 \%$ female, $63 \%$ male) they choose to live with a host family was because "I wanted to live with locals." This is a simple statement, but in reality defines a fundamental aspect of cultural immersion.

The six major groupings that the coded additional comments were broken down into included: Exceptional Home Stay Experience (Females), Exceptional 
Table 3: Qualitative Data Categorical Analysis, top five categories.

(Percents may total more than $100 \%$ as most students commented on various topics, and are rounded to nearest whole number.)

\begin{tabular}{|c|c|c|c|}
\hline$\%$ & $\begin{array}{l}\text { Exceptional Home Stay Experience } \\
\text { Female Responses }\end{array}$ & $\%$ & $\begin{array}{l}\text { Exceptional Home Stay Experience } \\
\text { Male Responses }\end{array}$ \\
\hline $\begin{array}{l}28 \% \\
\\
11 \% \\
9 \% \\
9 \% \\
9 \% \\
8 \% \\
6 \%\end{array}$ & $\begin{array}{l}\text { Language/Culture (immersion, } \\
\text { learning, etc.) } \\
\text { Freedom/Independence/Privacy } \\
\text { Treated as part of family } \\
\text { Still in touch with Host Family } \\
\text { Overall match (good/bad) } \\
\text { Welcoming \& Comfortable } \\
\text { Environment } \\
\text { Services (meals, laundry, } \\
\text { accommodations) }\end{array}$ & $\begin{array}{l}34 \% \\
12 \% \\
10 \% \\
10 \% \\
7 \% \\
7 \% \\
7 \% \\
7 \% \\
5 \% \\
\\
5 \% \\
5 \% \\
5 \%\end{array}$ & $\begin{array}{l}\text { Language/Culture (immersion, } \\
\text { learning, etc.) } \\
\text { Freedom/Independence/Privacy } \\
\text { Welcoming \& Comfortable } \\
\text { Environment } \\
\text { Overall match (good/bad) } \\
\text { Interaction with locals } \\
\text { Acclimate to new environment } \\
\text { Still in Touch with Host Family } \\
\text { Family had children } \\
\text { Services (meals, laundry, } \\
\text { accommodations) } \\
\text { Companionship/Friendship/Caring } \\
\text { Treated as part of family } \\
\text { Family met student's } \\
\text { needs/accommodating }\end{array}$ \\
\hline$\%$ & $\begin{array}{l}\text { Satisfactory Home Stay } \\
\text { Experiences } \\
\text { Female Reponses }\end{array}$ & $\%$ & $\begin{array}{l}\text { Satisfactory Home Stay } \\
\text { Experiences } \\
\text { Male Responses }\end{array}$ \\
\hline $\begin{array}{l}16 \% \\
9 \% \\
9 \% \\
7 \% \\
5 \% \\
4 \%\end{array}$ & $\begin{array}{l}\text { Language/Culture (immersion, } \\
\text { learning, etc.) } \\
\text { Freedom/Independence/Privacy } \\
\text { Treated as part of family } \\
\text { Overall match (good/bad) } \\
\text { Services (meals, laundry, } \\
\text { accommodations) } \\
\text { Apartment preferred }\end{array}$ & \begin{tabular}{l|}
$15 \%$ \\
$15 \%$ \\
$15 \%$ \\
$5 \%$ \\
\\
$5 \%$ \\
$2 \%$ \\
$2 \%$ \\
$2 \%$ \\
$2 \%$ \\
$2 \%$ \\
$2 \%$
\end{tabular} & $\begin{array}{l}\text { Language/Culture (immersion, } \\
\text { learning, etc.) } \\
\text { Freedom/Independence/Privacy } \\
\text { Overall match (good/bad) } \\
\text { Services (meals, laundry, } \\
\text { accommodations) } \\
\text { Interaction with Locals } \\
\text { Welcoming \& Comfortable } \\
\text { Environment } \\
\text { Acclimate to new environment } \\
\text { Treated as part of family } \\
\text { Family had children } \\
\text { Still in touch with Host Family }\end{array}$ \\
\hline$\%$ & $\begin{array}{l}\text { Unsatisfactory Home Stay } \\
\text { Experience } \\
\text { Female Responses }\end{array}$ & $\%$ & $\begin{array}{l}\text { Unsatisfactory Home Stay } \\
\text { Experience } \\
\text { Male Responses }\end{array}$ \\
\hline $\begin{array}{l}4 \% \\
4 \% \\
4 \% \\
4 \% \\
4 \% \\
3 \% \\
\\
3 \\
1 \% \\
\\
\end{array}$ & $\begin{array}{l}\text { Freedom/Independence/Privacy } \\
\text { Treated as part of family } \\
\text { Family's reason for hosting } \\
\text { Apartment preferred } \\
\text { Overall match (good/bad) } \\
\text { Services (meals, laundry, } \\
\text { accommodations) } \\
\text { Expectations (too high/too low) } \\
\text { Language/Culture (immersion, } \\
\text { learning, etc.) } \\
\text { Size of family (large/small) }\end{array}$ & $\begin{array}{l}2 \% \\
2 \% \\
2 \% \\
2 \% \\
2 \%\end{array}$ & $\begin{array}{l}\text { Language/Culture (immersion, } \\
\text { learning, etc.) } \\
\text { Freedom/Independence/Privacy } \\
\text { Services (meals, laundry, } \\
\text { accommodations) }\end{array}$ \\
\hline
\end{tabular}

Home Stay Experience (Males), Satisfactory Home Stay Experience (Females), Satisfactory Home Stay Experience (Males), Unsatisfactory Home Stay Experience (Females), and Unsatisfactory Home Stay Experience (Males). In 5 out of 
the 6 groupings, the top category in each group was "Language and Culture," which included cultural immersion, exposure, language, and learning. Both male and female students who had exceptional and satisfactory home stay experiences (based on the additional comments section) noted that the home stay was necessary for immersion and exposure to the culture or language of the host country. Similarly, those students who had unsatisfactory home stay experiences (based on the additional comments section) noted that they were not integrated into the family as much as they would have liked, which ultimately prevented them from reaching the level of cultural immersion they wanted. Based on this data, the following theories can be drawn:

Theory \#1: Both male and female study abroad participants who desire home stay experiences do so because they perceive that this living arrangement will allow them to experience a high degree of cultural immersion.

Theory \#2: Both male and female study abroad participants perceive cultural immersion, gained from a home stay experience, as being necessary for a study abroad experience to be considered a "successful learning experience."”

Theory \#3: Because cultural immersion creates a high degree of emotional intensity and because both male and female study abroad participants desire cultural immersion from a home stay experience (See Theory \#1), then male and female study abroad participants perceive that some degree of intensity will occur, or is necessary, in order for their study abroad experience to be a learning experience.

On the other hand, the intensity of the study abroad experience, and subsequent immersion, is somewhat lessened by the presence of a roommate, who is typically another student. The majority of the respondents from this research had at least one roommate during the home stay; 451 students out of the total 628 respondents or approximately $72 \%$ of the respondents indicated that he or she had a roommate. In addition, students are able to interact with one another during excursions, at the on-site office, and in classes or while studying at the host university. The students use the same facilities and strong friendships often are formed between students, as they are able to relate and share their experiences. Based on this data, and in connection with Theories $1-3$, the following theory can be drawn: 
Theory \#4: Study abroad participants are immersed in the culture during a home stay, thus creating a high degree of emotional intensity; the presence of a roommate in the home, lessens the level of intensity felt by each participant, despite the high degree of cultural immersion.

Based on the additional comments by the respondents, having independence is an important aspect during a home stay. The Freedom, Independence, \& Privacy Category was the second most popular category for females and males who had exceptional home stays, females and males who had satisfactory home stays, and males who had unsatisfactory home stays. This was the most commented upon category for females who had unsatisfactory experiences. Based on this data, the following theory can be drawn:

Theory \#6: Despite the difference between gender dynamics of power and control, BOTH male and female students perceive their freedom and independence as crucial to a successful home stay experience.

\section{Conclusions}

In addition to the theories presented above, there are several conclusions that can be drawn from data produced in this study. There is however, insufficient data to generate a theory based on the following conclusions:

- Female students evaluate the home stay experience as successful if the host family is missed, if it was emotional for both sides to say goodbye, or if the student has continued to communicate with the host family (letters, email) after returning to the United States.

- Female students who had a roommate with a significantly higher or lower language level, believe that this impacted (hindered or helped) their ability to interact with the host family.

- Both male and female study abroad participants necessitate having independence and freedom within the home stay environment.

- A male or female student, who does not feel that he or she is being given an adequate amount of freedom/independence by the host family, will hold a negative perception of the home stay. 
- Male students believe it is important to live with a host family who has children of any age in the home.

- Male students place significance on being in a welcoming and comfortable environment while living with a host family.

- Male students feel that the services the host family provides (food, laundry, shelter, electricity) should be satisfactory and meet their needs. (3\% of male students, who changed host families, did so because their dietary needs were not met).

Based on the data collected in this study, the female students generally felt that they had a satisfactory home stay if: 1) they learned from the experience, 2) they were given freedom and independence, 3) they were treated as part of the family, 4) they are still in touch with host family, 5) they were well-matched/ compatible with their host family, and 6) felt that the host family provided adequate services during their stay. The male students generally felt that they had a satisfactory home stay if: 1) they were immersed in the language and culture, 2) they were given freedom and independence, 3) they were provided a comfortable and welcoming environment, 4) they were well-matched/compatible with their host family, 5) they were able to interact with locals, and 6) they felt that the host family provided adequate services during their stay.

In summary, the data presented above demonstrates that male and female students have relatively similar views about the host family experience. Both genders recognize the importance of the home stay to cultural exposure, including fostering language learning and insights into the host culture. Male and female students alike recommended staying with a host family while studying abroad.

\section{B i b li o g r a p h y}

Belenky, Mary. (1996). Women's Ways of Knowing: The Development of Self, Voice and Mind, 10th Anniversary Edition. New York, NY: Basic Books.

Bennett, Milton J. (1993). “Towards Ethnorelativism: A Developmental Model of Intercultural Sensitivity." In Education for the Intercultural Experience 2nd Edition. Yartmouth, Maine: Intercultural Press Inc.

Borgatti, Steve. (Date of Publication Unknown). Introduction to Grounded Theory. Retrieved December 22, 2004 from: http://www.analytictech. com/mb870/introGT.htm 
Centers for Interamerican Studies (CEDEI). (1994-2004). Living With A Host Family: Cultural \& Practical Advice. Center for Interamerican Studies, Inc. Retrieved November 12, 2004 from: http://www.cedei.org/cuenca/ depts/oip/orientation/host_families.pdf

De Wit, Hans. Internationalization of Higher Education in the United States of America and Europe: A Historical, Comparative, and Conceptual Analysis. (2002). Westport, Connecticut: Greenwood Press.

Gilligan, Carol. (1993). In a Different Voice: Psychological Theory and Women's Development. Portland, Oregon: Book News Inc.

Hoffa, Bill \& Pearson, John, Eds. (1997).NAFSA’s Guide to Education Abroad for Advisers and Administrators, 2nd Ed. Washington D.C.: NAFSA: Association of International Educators.

Institute of International Education. (2003). Open Doors Report: Profile of U.S. Study Abroad Students. Retrieved Dec. 23, 2004 from http://opendoors.iienetwork.org/? $\mathrm{p}=49953$.

Martin, Judith \& Nakayama, Thomas. (1997). Intercultural Communication in Contexts.Mountain View, California: Mayfield Publishing Company

Noddings, Nell. (2003). Caring: A Feminine Approach to Ethics and Moral Education, 2nd Edition. Berkeley, California: The University of California Press.

Noddings, Nell. (1993). In A Different Voice: Psychological Theory and Women's Development. Cambridge, Massachusetts: Harvard University Press.

Orbe, Mark \& Harris, Tina. (2001). Interracial Communication: Theory into Practice. Belmont, California: Wadsworth/Thompson Learning Inc.

Paige, Michael. (1993). Education for the Intercultural Experience 2nd Edition. Yarmouth, Maine: Intercultural Press Inc.

Richardson, K. (2003). International Education: Home Stay Theory versus Practice. In Educational Research, Risks, \& Dilemas: NZARE/AARE Conference Nov. 29, 2003; Auckland, New Zealand. Retrieved Nov. 12, 2004 from: http://www.aare.edu.au/03pap/ric03173.pdf.

Richardson, Laura. (2003). Feminist Frontiers. New York, NY: McGraw-Hill Companies.

Rossman, Gretchen B. \& Rallis, Sharan F. (2003). Learning In the Field: An Introduction to Qualitative Research 2nd Ed. Thousand Oaks, California: Sage Publications, Inc.

Samovar, Larry \& Porter, Richard. (2003). Intercultural Communication. A Reader,

10th Edition. Belmont, California: Wadsworth/Thompson Learning.

Stewart, Edward \& Bennett, Milton. (1991). American Cultural Patterns: A 
Cross-Cultural Perspective, Revised Edition. Yarmouth, Maine: Intercultural Press Inc.

Storti, Craig. (2001). The Art of Crossing Cultures, 2nd Edition. Yarmouth, Maine: Intercultural Press, Inc.

Sumka, Shoshanna. (2001). Host Family Experience: What Is the Impact? What Does it Mean? Transitions Abroad Magazine, Sept/Oct 2001. Retrieved Nov 12, 2004 from:http:www.transitionsabroad.com/publications/magazine/0109/host_family_experience.shtml.

Tannen, Deborah, Ph.D. (2001). You Just Don't Understand: Women and Men In Conversation. New York, NY: First Quill HarperCollins Publishers

Twombly, Susan B. (1995). Piropos and Friendships: Gender and Culture Clash in Study Abroad. Frontiers: The Interdisciplinary Journal of Study Abroad, Vol. 1 Fall 1995. Retrieved Nov.12, 2004 from: http:www.frontiersjournal.com/issues/vol1-01_twombly.htm

Wilkinson, Sharon. (1998). On the Nature of Immersion During Study Abroad: Some Participant Perspectives. Frontiers: The Interdisciplinary Journal of Study Abroad, Vol. IV, Fall 1998;pp. 121-138. Retrieved November 12, 2004 from: http://www.frontiersjournal.com/issues/vol4/ vol4-05_wilkinson.pdf

Wood, Julia \& Reich, Nina. (2003). Gendered Speech Communities. In Samovar, Larry \& Porter, Richard. (2003). Intercultural Communication. A Reader, 10th Edition (pp. 144-154). Belmont, California: Wadsworth/ Thompson Learning. 